\title{
Migrena sergančių ligonių konsultavimas ir gydymas COVID-19 pandemijos metu
}

\author{
K. Ryliškienè \\ Vilniaus universiteto Medicinos \\ fakultetas, Klinikines medicinos \\ institutas, Neurologijos centras
}

\begin{abstract}
Santrauka. COVID-19 pandemijos metu ribojant ligonių apsilankymus prièmimo-skubios pagalbos skyriuose, nevykdant planinio konsultavimo, iškyla sunkumų optimaliai gydyti migreną. Literatūros apžvalgoje pateikiama informacija apie migrena sergančio ligonio nuotolinio konsultavimo galimybes, paciento pasiruošimą konsultacijai, priepuoliui ir profilaktikai skirtų vaistų saugų vartojimą, ịprasto ir sunkaus migrenos priepuolio gydymo strategijas. Taip pat supažindinama su asmens apsaugos priemonių sukeliamu galvos skausmu.
\end{abstract}

Raktažodžiai: migrena, COVID-19, nuotolinis konsultavimas, gydymas, asmens apsaugos priemonès.

\begin{abstract}
IVADAS
$2020 \mathrm{~m}$. kovo $11 \mathrm{~d}$. Pasaulio sveikatos organizacijai paskelbus COVID-19 pandemiją, iškilo sunkumų optimaliai gydyti migreną, dèl kurios pacientai dažnai kreipiasi skubios pagalbos ir sudaro didelę dalị planinių šeimos gydytojų bei neurologų konsultacijų. JAV duomenimis, stiprus galvos skausmas yra penktas pagal dažnị susirgimas (tarp jaunų ir vidutinio amžiaus moterų - trečias), dèl kurio vyksta konsultacijos priemimo-skubios pagalbos skyriuje (PSPS). Galvos skausmas sudaro 3,0 \% visų PSPS konsultacijų, o migrena - $0,8 \%$. Dažnesnès už galvos skausmą apsilankymo prièmimo skyriuje priežastys yra pilvo, krūtinès skausmas, kosulys ir karščiavimas [1]. Karantino metu PSPS konsultacijų dèl migrenos labai sumažèjo. Vilniaus universiteto ligoninės Santaros klinikų PSPS nuo $2020 \mathrm{~m}$. kovo $16 \mathrm{~d}$. iki balandžio $16 \mathrm{~d}$. neurologai konsultavo 252 pacientus, iš jų $10(4,0 \%)$ - dèl galvos skausmo ir $2(0,79 \%)$ - dèl migrenos, kaip pagrindinio nusiskundimo. Palyginimui $2019 \mathrm{~m}$. tuo pačiu metu neurologai konsultavo 543 pacientus, iš jų $64(11,8 \%)$ - dèl galvos skausmo ir $15(2,8 \%)$ - dèl migrenos. Pateikti skaičiai rodo, kad vie-
\end{abstract}

\author{
Adresas: \\ Kristina Ryliškienè \\ Vilniaus universiteto ligonine Santaros klinikos, \\ Neurologijos centras \\ Santariškiu g. 2, LT-08661 Vilnius \\ El.paštas kristina.ryliskiene@santa.lt
}

nas iš karantino tikslu pasiektas - ligoniai dèl galvos skausmo daug rečiau kreipiasi į PSPS. Bet ar tai rodo pagerejjusį migrenos gydymą namie, ar baimę vykti ị ligoninę, o gal iki karantino didžiajai daliai ligonių apskritai nebuvo skubios konsultacijos indikacijų? $2014 \mathrm{~m}$. JAV atlikto tyrimo duomenimis, beveik pusè ị prièmimo skyrių atvykstančių migrena sergančių ligonių neturẻjo nustatytos migrenos diagnozès (45\%) ir atvykimo dieną nevartojo vaistų nuo skausmo (45\%) [2], todèl galime manyti, kad dalis pacientų iš viso neturi žinių, kaip gydyti stiprų migrenos priepuoli namuose, o kiti tiesiog naudojasi skubaus konsultavimo ir gydymo galimybe, aplenkdami planinio konsultavimo eiles.

Literatūros apžvalgoje pateikiama informacija apie migrena sergančio ligonio nuotolinio konsultavimo galimybes, tinkamą ligonio pasiruošimą tokiai konsultacijai, priepuoliui ir profilaktikai skirtų vaistų saugų vartojimą, iprasto ir sunkaus migrenos priepuolio gydymo strategijas. Taip pat supažindinama su asmens apsaugos priemonių sukeliamu galvos skausmu.

\section{SERGANČIŲJŲ MIGRENA KONSULTAVIMAS}

Nuotolinės garso ir (ar) vaizdo konsultacijos pagrindiniuose JAV ir Europos galvos skausmo centruose nèra naujiena. Taip konsultuojami pakartotiniai pacientai su nustatyta diagnoze, vertinamas skirto gydymo veiksmingumas, koreguojamas medikamentinis gydymas, išrašomi vaistai,

(C) Neurologijos seminarai, 2020. Open Access. This article is distributed under the terms of the Creative Commons Attribution 4.0 International License CC-BY 4.0 (http://creativecommons.org/licenses/by/4.0/), which permits unrestricted use, distribution, and reproduction in any medium, provided you give appropriate credit to the original author(s) and the source, provide a link to the Creative Commons license, and indicate if changes were made. 
įvertinami atliktų tyrimų rezultatai. Nustatyta, kad nuotolinis konsultavimas yra ekonomiškas ir patogus pacientui, ypač dirbančiam, gyvenančiam atokiai nuo konsultacijos vietos. Nemažai veiksnių, iš kurių svarbiausi - technologinės galimybės, paciento asmens duomenų apsauga, sveikatos apsaugos sistemų inertiškumas - stabdè platesnị nuotolinio konsultavimo taikymą [3]. Karantino metu keliami du konsultavimo tikslai: naujo ar pasikeitusio skausmo diferenciné diagnostika (1 lentelè) ir skausmo gydymas. Pacientui prieš nuotolinę konsultaciją rekomenduojama užsirašyti jam kylančius klausimus, pasižymèti dienų su galvos skausmu skaičiu per mėnesį, labai stipraus skausmo dienų skaičiu per mėnesį, dienų su vaistais skaičiu per mėnesi (angl. 3 Fs: headache Frequency, Functional impact, medication use Frequency). Tureti visų vartojamų vaistų ir jų dozių sąrašą [4].

\section{MIGRENOS PRIEPUOLIUI IR PROFILAKTIKAI SKIRTŲ VAISTU SAUGUMAS}

Renino-angiotenzino sistemos blokatoriai ir nesteroidiniai vaistai nuo uždegimo (NVNU). Remiantis dabartiniais duomenimis, migrenos priepuolių gydymas ibuprofenu ir profilaktinis gydymas lizinopriliu (angiotenzino konvertuojančio fermento inhibitoriumi) ar kandesartanu (angiotenzino II 1 tipo receptoriaus blokatoriumi) nedidina rizikos sirgti COVID-19 ir neblogina sergančiųjų būklès. Jei šiais vaistais migrenos priepuolių stiprumas ir dažnis iki COVID-19 pandemijos buvo gerai valdomas, gydymą rekomenduojama tęsti. Vaistų nuo kraujospūdžio nutraukimas migrena sergantiems pacientams, kurie turi gretutinę širdies kraujagyslių ligą, gali būti žalingas [6].

Kortikosteroidų skyrimo sunkiam migrenos priepuoliui šiuo metu rekomenduojama vengti dèl galimos viruso replikacijos pailgèjimo. Jei pacientas neserga COVID-19, neturi gretutinių ligų ir imunodeficito, nèra saviizoliacijoje dèl buvusio kontakto su COVID-19 sergančiu ligoniu, gydytojo sprendimu kortikosteroidai gali būti skiriami [3].

Monokloniniai antikūnai prieš su kalcitonino genu susijusį peptidą (angl. Calcitonine Gene Related Peptide, CGRP) ar jo receptorių neturi poveikio imuninei sistemai, todèl gali būti saugiai skiriami. Jei lètinè migrena yra gydoma onabotulinotoksinu A, šiuo metu rekomenduojama svarstyti pakeisti ši gydymą monokloniniais antikūnais prieš CGRP ar jo receptoriu, taip mažinant paciento ir gydytojo tiesioginį kontaktą [3].

\section{MIGRENOS PRIEPUOLIO GYDYMAS}

Ligoniui turi būti rekomenduojamas ne vienintelis (pirmo pasirinkimo vaistas), bet ir pagalbinis (antro pasirinkimo vaistas) bei nuo labai sunkaus priepuolio gelbstintis gydymo planas. Geriausia, kad pacientas turètų vaistų atsargų 90 dienų. Reikia priminti, kad vaistai turi būti išgerti laiku (kuo anksčiau, priepuoliui prasidejus) ir tinkamos
1 lentelè. İspẻjamieji pavojingo simptominio skausmo požymiai [5]

\begin{tabular}{||l|l||}
\hline \hline SNOOP atmintiné & Paaiškinimas \\
\hline Sisteminiai simptomai & $\begin{array}{l}\text { Karščiavimas, šaltkrètis, svorio } \\
\text { kritimas, ŽIV infekcija, věžio } \\
\text { anamnezé* }\end{array}$ \\
\hline $\begin{array}{l}\text { Neurologiniai simptomai } \\
\text { ir požymiai }\end{array}$ & $\begin{array}{l}\text { Kiekybinis ir kokybinis sąmonės } \\
\text { pakitimas, traukulinis sindromas, } \\
\text { židinine neurologinė simptomatika }\end{array}$ \\
\hline Staigi pradžia (angl. Onset) & Staigi skausmo pradžia \\
\hline $\begin{array}{l}\text { Vyresnis pacientas (angl. } \\
\text { Older patient) }\end{array}$ & $\begin{array}{l}\geq 50 \text { metu pacientui naujai atsira- } \\
\text { dęs arba progresuojantis galvos } \\
\text { skausmas }\end{array}$ \\
\hline $\begin{array}{l}\text { Galvos skausmo } \\
\text { anamnezè (angl. } \text { Previous } \\
\text { headache history) }\end{array}$ & $\begin{array}{l}\text { Pasikeitęs buvęs skausmas - padaž- } \\
\text { nėjęs, sustiprèjęs, pakitęs pobūdis, } \\
\text { nebeveiksmingas buvęs gydymas }\end{array}$ \\
\hline
\end{tabular}

SNOOP - lietuviškai šnipinėtojas, ŽIV - žmogaus imunodeficito virusas

*kiti reikšmingi anamnezės duomenys - imunosupresinių vaistų, antikoaguliantų, hormoninès kontracepcijos vartojimo anamnezè, pandemijos metu anamnezę galime papildyti viena aplinkybe - kontaktas su COVD-19 sergančiu asmeniu (autorès pastaba)

dozės; greitesniam poveikiui ir esant pykinimui ar vėmimui tinkamos parenterinès formos - diklofenako rektalinès žvakutės, NVNU raumeninės injekcijos (vaistą gali susileisti pats pacientas arba suleisti jo artimasis); stipresniam poveikiui saugu vartoti triptano, NVNU, antiemetiko derinius. Jei priepuolis yra labai stiprus, skiriami slopinamieji vaistai (diazepamo $5 \mathrm{mg}$ tabletè), leidžiantys pacientui užmigti ir taip nutraukiantys priepuolị. Vaistų nuo skausmo vartojimas neturètų viršyti 10 dienų per mėnesi [4].

Labai stipraus ar užsitęsusio priepuolio gydymas trumpalaike profilaktika (angl. bridge therapy) neturi tvirtụ ịrodymų, bet, siekiant išvengti apsilankymo PSPS, gali būti veiksmingas (2 lentelè) [3].

\section{MIGRENOS PROFILAKTIKA}

Pacientams svarbu nepamiršti dienos rutinos: laikytis miego ir mitybos režimo, reguliariai sportuoti [4]. Gydytojams svarbu laiku skirti medikamentinę profilaktiką, t. y., kai stiprūs migrenos priepuoliai kartojasi kartą per savaitę ir dažniau, o jau paskirtą profilaktiką tęsti bent 6-12 mènesių. Vaistus rekomenduojama rinktis remiantis įrodymais pagrịsta medicina, atsižvelgiant ị galimus nepageidaujamus reiškinius ir kontraindikacijas [3]. Lietuvos galvos skausmo specialistai džiaugiasi, kad COVID-19 pandemijos metu, kai migrena tikrai nėra prioritetinè medicinos ir neurologijos sritis, Vaistinių preparatų ir medicinos pagalbos priemonių kompensavimo komisijos sprendimu monokloninis antikūnas prieš CGRP receptorių erenumabas ịtrauktas ị kompensuojamųjų vaistų sąrašą, skiriant jị migrenos profilaktikai suaugusiesiems, kuriems pasireiškia 
2 lentelè. Trumpalaikè profilaktika stipraus ar užsitęsusio migrenos priepuolio metu [3]

\begin{tabular}{|c|c|}
\hline Vaistas, dozavimas & Pastabos \\
\hline Indometacinas $75 \mathrm{mg}$, gerti 2 kartus per dieną 7 dienas & \multirow{4}{*}{$\begin{array}{l}\text { Nesteroidiniai vaistai nuo uždegimo neskiriami, jei } \\
\text { anamnezejje buvęs kraujavimas iš virškinamojo trakto, } \\
\text { yra inkstu ir širdies nepakankamumas, ūminiai } \\
\text { koronariniai sindromai. }\end{array}$} \\
\hline Ketorolakas $10 \mathrm{mg}$, gerti 3 kartus per dieną 3 dienas & \\
\hline Natrio naproksenas $550 \mathrm{mg}$, gerti 2 kartus per dieną 5-14 dienų* & \\
\hline Diklofenakas $50 \mathrm{mg}{ }^{* *}$, gerti 2 kartus per dieną 3-5 dienas & \\
\hline Metoklopramidas 5-10 mg, gerti 3 kartus per dieną arba nakčiai 3 dienas & \multirow{3}{*}{$\begin{array}{l}\text { Dopamino antagonistai slopina pykinimą, vėmimą, gali } \\
\text { sukelti mieguistumą (tinka sutrikus miegui), ekstrapirami- } \\
\text { dinius simptomus (vengti ilgalaikio skyrimo), ilgina QT. }\end{array}$} \\
\hline Olanzapinas $5 \mathrm{mg}$, gerti nakčiai arba 2 kartus per dieną 3-5 dienas & \\
\hline Kvetiapinas $25-50 \mathrm{mg}$, gerti nakčiai 7 dienas & \\
\hline Frovatriptanas $2,5 \mathrm{mg}$, gerti 2 kartus per dieną 3 dienas & \multirow[t]{2}{*}{ Prevencijai skiriami ilgai veikiantys triptanai. } \\
\hline Naratriptanas 2,5 mg, gerti 2 kartus per dieną 3 dienas & \\
\hline $\begin{array}{l}\text { Deksametazonas } 6 \mathrm{mg} \text {, gerti rytais valgio metu } 3 \text { dienas, jei poveikio } \\
\text { nepakanka, tęsti po } 4 \mathrm{mg} 3 \text { dienas ir po } 2 \mathrm{mg} 3 \text { dienas } * * *\end{array}$ & Kortikosteroidai skiriami atsargiai. \\
\hline $\begin{array}{l}\text { Valproinè rūgštis } 500-1000 \mathrm{mg} \text {, gerti nakčiai } 5 \text { dienas arba } \\
250 \mathrm{mg} 3 \text { kartus per dieną 5-7 dienas }\end{array}$ & Neskiriama vaisingo amžiaus moterims. \\
\hline Amitriptilinas $25 \mathrm{mg}$, gerti nakčiai 7-14 dienas & Ypač tinka, jei kartu yra sutrikęs miegas. \\
\hline Tizanidinas 4-8 mg, gerti nakčiai 7 dienas & Ypač tinka, jei kartu yra kaklo ar raumenų skausmas. \\
\hline Magnio citratas 300-400 mg, gerti 2 kartus per dieną 3-5 dienas & Ypač tinka migrenai su aura. \\
\hline
\end{tabular}

*ilgai skiriant, vertètų rinktis naprokseno $500 \mathrm{mg}$ ir ezomeprazolio $20 \mathrm{mg}$ derini (autorès pastaba),

**Lietuvoje mažiausia Na diklofenako dozè tabletėje $75 \mathrm{mg}$ (autorés pastaba),

***Lietuvoje dažniau taikoma raumeninė injekcija $8 \mathrm{mg}$ rytais 3 dienas ir po to $4 \mathrm{mg}$ rytais 3 dienas.

bent 4 dienos su migrenos skausmu per mėnesį [7]. Taigi, klinikinejje praktikoje galėsime taikyti veiksmingą, gerai toleruojamą ir patogią naudoti specifinę migrenos prevenciją.

\section{ASMENS APSAUGOS PRIEMONIŲ SUKELTAS GALVOS IR VEIDO SKAUSMAS}

Pagal Tarptautinę galvos skausmo klasifikaciją, išorinio suspaudimo sukeliamas skausmas priklauso kitų pirminių galvos skausmų grupei [8]. Literatūroje medicininių asmens apsaugos priemonių (AAP) sukeltas galvos skausmas pirmą kartą aprašytas 2003 m. Singapūre per SŪRS (sunkus ūminis respiracinis sindromas) epidemiją [9]. Manoma, kad skausmui atsirasti yra svarbus ne tik mechaninis galvos ir veido spaudimas, bet ir terminis diskomfortas, apsunkintas kvėpavimas. $2020 \mathrm{~m}$. vasario ir kovo mèn. Singapūro nacionalinėje universiteto ligoninèje vykdytas skerspjūvio tyrimas, kurio metu apklausti 158 medicinos darbuotojai $(64,6 \%$ - slaugytojos, 32,3\% - gydytojai ir $3,2 \%$ - pagalbinis personalas), kurie vidutiniškai 18,3 dienos per ménesi 5,9 val. per dieną dèvejjo AAP. $128(81,0 \%)$ tiriamiesiems nustatytas naujai atsiradęs galvos ir veido skausmas, susijęs su asmens apsaugos priemonių (N95 respiratorių, kurių atitikmuo Lietuvoje yra FFP2 respiratoriai, ir akinių) naudojimu. Jau turimas pirminis galvos skausmas (OR 4,2; $p=0,3$ ) ir AAP suminio naudojimo trukmė, ilgesnè nei 4 val. per parą (OR 3,91; $\mathrm{p}=0,012$ ), buvo nepriklausomi skausmo atsiradimo veiksniai. Dažniausiai per 60 min. nuo AAP naudojimo atsirandantis ir per 30 min. po naudojimo praeinantis skausmas buvo jaučiamas nosies, skruostų, smilkinių, kaktos, re- čiau - pakaušio, kaklo srityse. Skausmas buvo apibūdinamas kaip spaudžiantis (87,5 \%), silpnas (71,9\%), be lydinčių reiškinių ir vaistų nuo skausmo vartojimo (68,8 \%). Rečiau - pulsuojantis $(11,7 \%)$, su lydinčiais migreniniais reiškiniais $(23,4 \%)$ ir vaistų vartojimu. Nors nedidelį, bet neigiamą skausmo poveikị darbingumui nurodė $82,8 \%$ apklaustujų, o nedarbingumo pažyma dèl stipraus galvos skausmo suteikta $9(7,0 \%)$ tiriamiesiems. 91,3\% jau turinčių pirminį galvos skausmą tiriamųjų nurodè jo pablogejjimą, kuris galètų būti susijęs su darbu pandemijos metu: miego deprivacija, fiziniu ir emociniu stresu, nereguliariu maitinimusi ir nepakankamu skysčių vartojimu [10]. Tyrimo rezultatai atkreipé demesị i kokybiškų, tinkamo dydžio ir formos AAP poreikị bei optimalią jų naudojimo trukmę.

\section{NEATSAKYTI KLAUSIMAI}

Dviejų metaanalizių duomenimis, 12-15,4 \% COVID-19 segančiųjų skundžiasi galvos skausmu [11, 12], kuris yra dažniau nustatomas karščiuojantiems pacientams $(p<0,001)$ [13]. Kaip atpažinti simptominị COVID-19 sukeltą galvos skausmą, jei dar nėra karščiavimo ir kitų dažniausių infekcijos požymių? Ar migrena sergantiems ligoniams infekcijos sukeltas galvos skausmas yra dažnesnis? Ar jis turi būdingą fenotipą (pvz., îtampos tipo ar trigeminalinès neuralgijos)? Ar naujos migrenos priepuoliui gydyti skirtos gepantų klasės vaisto vazegepanto nosies purškalas bus veiksmingas, slopinant „citokinų audrą“" labai sunkiems COVID-19 sergantiems ligoniams [14]? Atsakymų ị šiuos ir kitus klausimus tikimasi sulaukti pasibaigus pandemijai [15]. 


\section{Literatūra}

1. Burch R, Rizzoli P, Loder E. The prevalence and impact of migraine and severe headache in the United States: figures and trends from government health studies. Headache 2018; 58(4): 496-505. https://doi.org/10.1111/head.13281

2. Minen MT, Loder E, Friedman B. Factors associated with emergency department visits for migraine: an observational study. Headache 2014; 54(10): 1611-8. https://doi.org/ 10.1111/head.12461

3. Szperka CL, Ailani J, Barmherzig R, et al. Migraine care in the era of COVID-19: clinical pearls and plea to insurers. Headache 2020; 60(5): 833-42. https://doi.org/10.1111/ head. 13810

4. American Migraine foundation and American Headache Society webinar Migraine and COVID-19. Available from: https://americanmigrainefoundation.org/resource-library/ migraine-and-covid-19/

5. Dodick DW. Clinical clues and clinical rules: primary vs secondary headache. Adv Stud Med 2003; 3: S550-5.

6. MaassenVanDenBrink A, de Vries T, Danser AHJ. Headache medication and the COVID-19 pandemic. J Headache Pain 2020; 21: 38. https://doi.org/10.1186/s10194020-01106-5

7. Vaistinių preparatų ir medicinos pagalbos priemonių kompensavimo komisijos $2020 \mathrm{~m}$. balandžio 3 d. posèdžio protokolas Nr. LKV-12/20. Prieiga per internetą: http://sam.lrv.lt/ uploads/sam/documents/files/2020-04-03\%20vie\%C5\% A1as $\% 20$ protokolas.pdf

8. The International Classification of Headache Disorders, 3rd edition. Cephalalgia 2018; 38(1): 1-211. https://doi.org/ $10.1177 / 0333102417738202$

9. Lim ECH, Seet RCS, Lee KH, et al. Headaches and the N95 face-mask amongst healthcare providers. Acta Neurol Scand 2006; 113(3): 199-202. https://doi.org/10.1111/j.16000404.2005.00560.x

10. Ong JJY, Bharatendu C, Goh Y, et al. Headaches associated with personal protective equipment - a cross-sectional study among frontline healthcare workers during COVID-19.
Headache 2020; 2020: 864-77. https://doi.org/10.1111/ head.13811

11. Borges do Nascimento IJ, Cacic N, Abdulazeem HM, et al. Novel coronavirus infection (COVID-19) in humans: a scoping review and meta-analysis. J Clin Med 2020; 9(4): 941. https://doi.org/10.3390/jcm9040941

12. Zhu J, Ji P, Pang J, et al. Clinical characteristics of 3,062 COVID-19 patients: a meta-analysis. J Med Virol 2020; 2020: 0-1. https://doi.org/10.1002/jmv.25884

13. Luo H, Lie Y, Prinzen FW. Surveillance of coronavirus disease 2019 in general population using an online questionnaire: a report from 18161 respondents in China. JMIR Public Heal Surveill 2020; 6(2): e18576. https://doi.org/ $10.2196 / 18576$

14. Robertson CE. Could CGRP antagonists be helpful in the fight against COVID-19? Headache 2020. https://doi.org/ 10.1111/head.13853

15. Wells RE, Strauss LD. The value of headache-specific recommendations during COVID-19. Headache 2020; 60(5): 820-3. https://doi.org/10.1111/head.13821

\section{K. Ryliškienè}

\section{MIGRAINE CONSULTATION AND TREATMENT IN THE ERA OF COVID-19}

\section{Summary}

During the COVID-19 pandemic, patients have limited access to scheduled visits and emergency departments; these limitations compromise the optimal care of migraine. This article reviews teleconsultation options, patient preparation for counselling, safe use of acute and preventive medications, and treatment strategies for typical and severe migraine attacks. The literature review also provides information on the headache associated with personal protective equipment.

Keywords: migraine, COVID-19, teleconsultation, treatment, personal protective equipment.

Gauta:

Priimta spaudai:

20200507 20200513 